I Universidade Federal do Rio Grande do Sul, Departamento

de Sociologia, Porto Alegre, RG, Brasil

weiss.raquel@gmail.com

https://orcid.org/000o-0002-59I I-4I47

Raquel Weiss'

\title{
BETWEEN THE SPIRIT AND THE LETTER: DURKHEIMIAN THEORY IN THE CULTURAL SOCIOLOGY OF JEFFREY ALEXANDER ${ }^{1}$
}

\section{PRELIMINARY REMARKS}

The social world is constituted by a web of meanings, a reticular version of Ariadne's thread internalized by subjects. Any attempt to comprehend human action thus requires us to apprehend the processes through which this web is produced, the associated meanings, its modes of subjectification and the sensation of objectivity produced - a condition for the illusion of certainty about the path taken in our everyday life. As we shall see, this formula constitutes the core of the program of cultural sociology developed by Jeffrey Alexander over the last three or four decades.

In an interview conducted with the author in $2014,{ }^{2}$ when I asked him about the relationship between his work on the theoretical logic of sociology and the development of his own theory and empirical research, he made clear how much this general premise is central to his thought: sociological knowledge is pervaded by the same logic, since the mind of the researcher operates according to the same processes as any social actor. Sociological inquiry is just a specific type of action in the world. In the following section of the interview, we can comprehend how Alexander connects his broader view of the social world and his specific localization in the field of sociological theory:

In the social sciences the idea circulates that the mind is not involved in the knowledge process: you just throw yourself and find reality. I want people to realize that it's a mental construction of the social world [...]. It is absurd to say 


\begin{abstract}
that we are finding 'what is really there.' It is a hermeneutic exercise: we are reconstructing reality according to theoretical ideas that we have. [...] A person's mind is extremely complicated and we do not understand our own thought, so one of the main themes of Theoretical Logic in Sociology is that you always have a symbolic or cultural or moral element, which gives the dimension of every action, of every organization, whether economic or religious. I argue for an analytic approach to culture, such that nothing goes without meaning; without this understanding, then you end up with a reduction. I follow that through Marx, Durkheim, Weber and Parsons, this theme that I later called the relative autonomy of culture (Alexander, 2019: n.p.)
\end{abstract}

Making explicit the guiding theoretical premises of an empirical research project is thus a condition for self-awareness and even autonomy on the researcher's part. I propose to take Alexander's argument seriously by using it as the starting point for this article. This proposal can be formulated as follows: understanding his strong program in cultural sociology - including its development towards a performance-centred pragmatic analysis - requires a reconstruction of the theoretical framework mobilized by the author, the epicentre of which involves his reinterpretation of Émile Durkheim's theory.

The image of Durkheim projected by Alexander reflects a time-honoured theoretical tradition: it comprises an interpretation that is also an invention. To summarize in one sentence the argument explored in the following pages: the interpretative construction of the US sociologist foregrounds aspects of Durkheim's work that have traditionally been little emphasized, the result of a creative reading focused on addressing his own concerns and capable of being mobilized as a structuring element of his own theory. As Alexander's theory takes shape, so the references to Durkheim's work tend to become more subtle, forming the foundations for other layers added over time.

The four sections in which this text is organized provide a chronological reconstruction of Alexander's relationship to Durkheim's work in which this general argument, the structure of this article, is diffused. In fact, it condenses two small theses, arising from a premise formulated by the author himself and from my own interpretation of this premise, which operates as a critical mediation of the former. The first thesis sustains Alexander's interpretative logic as a specific form of responding to the sociological tradition, based on a respect for theory, in particular classical theory. Consequently, I suggest that the treatment given to Durkheim's work contains an original contribution to the consolidation of the field of sociological theory itself, including its metatheoretical dimension.

The second thesis can be synthetically formulated as follows: Alexander produced in relation to Durkheim a shift similar to Lacan's in relation to Freud, relatively speaking. Put succinctly, the central twist of Alexander's endeavour involves a dense re-reading of Durkheim's work through a non-scientificist approach, foregrounding the symbolic dimension of human existence. In the process, a wide range of new possibilities for interdisciplinary discussions was 
opened up, including psychoanalysis, via an approach still to be sufficiently explored (Alexander, 201 3a: Chapter 8). This is the movement at the base of his real breakthrough: the construction of a coherent intellectual lineage whose common ancestor is Durkheim, especially "first-phase Durkheim." As we shall see, this is a movement that allowed roots to be identified in authors like Ferdinand de Saussure, Claude Lévi-Strauss, Victor Turner, Clifford Geertz, Roland Barthes, Talcott Parsons, Robert Bellah and so on, who consistently appear alongside one of the precursors of the hermeneutic tradition, Max Weber. By reconstructing Durkheim's image for his own purposes, the way was cleared for this reinvention of a tradition capable of sustaining his own project.

To understand the deeper meaning of the movement suggested in these two theses, we need to make explicit Alexander's basis premise in his treatment of the classical tradition, without which his construction would lack a solid base or, at the very least, would be much more susceptible to critique. This concerns the author's sui generis understanding of the role of the classics in the social sciences, formulated explicitly in the article "The Centrality of Classics" (Alexander, I987), in which he seeks to defend the study of the classics from two lines of attack, namely empiricism - in both its positivist and postpositivist versions - and historicist humanism. Despite taking distinct paths, one rejecting the very existence of the classics, the other turning them into the central object of a historical-empirical analysis, both deprive the classics of meaning for sociology, the outcome of an equivocal understanding of the actual nature of knowledge production as something always and necessarily mediated by a discourse.

In short, in the aforementioned article, Alexander mobilizes the theoretical framework of his cultural sociology - at the time still being consolidated and applies it to present a general overview of sociology as part of the social universe and subject, therefore, to the same logics. Like everything in social life, sociology only exists as a discourse articulated around symbols and meanings shared by the community, within which sociological theory performs a central role as a narrative capable of mediating with the 'real,' the latter never apprehensible in direct form. In terms of what concerns us more immediately here, this general premise unfolds into two interconnected arguments, one of them relating to the role of the classics in sociology and the other to the mode of approaching them. In relation to the first argument, the author sustains a double role: functional and intellectual (or scientific). The functional role is perhaps the most prominent and ultimately legitimizes its own form of dealing with the classical tradition - after all, Alexander argues that a set of classic authors needs to exist in order to establish something like a shared vocabulary, a language capable of being mobilized by members of the sociological community in the construction of their discourses. In this sense, what matters is not what the classics themselves actually are, but the mythological version constructed by tradition: 
To mutually acknowledge a classic is to have a common point of reference. A classic reduces complexity (Cf. Luhmann, 1979). It is a symbol which condenses - 'stands for' - a range of different commitments. [...] Even if no genuine concern for the classics exists, they still must be criticized, re-read or rediscovered if the discipline normative criteria for evaluation are to be challenged anew (Alexander, 1987: 27).

In relation to the intellectual or scientific role, the author restates his view of the importance of theory as a necessary mediation with the real. Producing theory does not depend on technical skills acquired over time or through close observance of some protocol, but is subject to idiosyncratic skills of experiencing, comprehending and knowing (see Alexander, I987: 28-30). The classics, therefore, were produced by figures endowed with these qualities, which is why their work goes beyond the mere description of social reality to produce a narrative about it, with ideas that were frequently beyond the comprehension of their contemporaries.

These two motives are intrinsically connected to his understanding of how the classics should be approached, grounded in the thesis of the nonseparation between history and systematics. In other words, Alexander considers the attempt to comprehend what an author means impossible - and even undesirable. Ultimately the act of writing lacks objectivity, not even its author has a precise awareness of what he or she wishes to say and much less what is effectively said: the text has its own life. Classical sociological theory is placed, therefore, on the same level as literature. Indeed, it is a form of literature and thus a creation, and this authorizes Alexander to seek support from figures like Roland Barthes and Paul Ricoeur in his confrontation of the historicist and contextualist approach led by Quentin Skinner, rejecting any attempt at theoretical reconstruction that bases itself on the belief that the truth of an author or a theory can be recovered. The only knowledge extractable from a sociological theory is the knowledge produced by an interpretation, one capable of producing new meanings through the voids and contradictions of the text itself and the concerns that say more about the reader-interpreter than the author:

Because profound ambiguity lies at the origin of most powerful imaginative works, Empson (1930) argued, texts are filled with unresolved contradictions and readers are forced to invent interpretations about meaning and authorial intent (Alexander, 1987: 49).

In the overall economy of Alexander's work, this general premise, structured in multiple layers, enables him to make a singular use of the theoretical tradition, especially its classic core texts. This needs to be taken into account, therefore, if we are to substantiate the two movements indicated in the arguments presented above. However, I wish to explore a number of critical angles relating to this premise, in particular so as to draw out the implications of Alexander's interpretations both from and for the area in which my own work is situated, namely the field of 'Durkheimian studies.' 
In relation to this field, informed by multiple competing readings, Alexander's interpretation represents a turning point insofar as it highlights the 'culturalist' contributions of the 'late Durkheim' - or, to use an expression more appropriate to our lexicon, 'the final phase' of Durkheim's work, with an emphasis on his writings on religious sociology. However, the originality implied in this turn was only made possible by taking his own argument seriously, namely that any attempt to discover what the author really wanted to say actually matters relatively little. From the viewpoint of the pretentions of a certain 'Durkheimology,' his reading lacks exegetical rigour: while Alexander's theory is strongly embedded in a Durkheimian mould, his work is not 'Durkheimological' properly speaking - at least in the sense of an investigation that privileges the reconstruction of internalist aspects and the consideration of historical data.

Up to this point, Alexander's interpretation seems entirely consistent with his premise. In order to establish a critical distance from certain aspects of his appropriation of Durkheim's work we need, therefore, to discuss his premise, not so as to reject it, but in order to introduce nuances capable of amplifying the potential of the approach suggested by the author himself. In short: I side with Alexander's idea of articulating context and analysis, as well as his notion of interpretation as a creative reading informed by contemporary concerns and needs, but I also argue that the better we know the universe of the classic author in question, the more interpretative possibilities become available. Knowing the context of the Dreyfus Affair and Durkheim's position on the issue, for example, allows us to offset interpretations like Nisbet's (I952) that situate the author as part of French conservatism and, in so doing, immediately undermine the author's critical potential. If there is something mythological in our relation to the classics, I believe that this can become more 'enlightened' and even more autonomous the more knowledge we can produce in their regard.

This evaluation is not intended to discredit Alexander's position in relation to the classics nor even the way in which he reconstructs Durkheimian theory. On the contrary, my intention to highlight the potential contained in the encounter between different forms of regarding the 'real.' The exegetical and historical work pursued in the field of Durkheimian studies enables us to detect important absences in Alexander's work. In the process, I hope to both focus debate on a number of specific arguments and explore the pertinence of various theses, but above all foreground other interpretative possibilities, not necessarily opposed but complementary. After all, as Alexander himself tells us, only when "the subtle interplay between absence and presence is understood can one see the theoretical function of the classics, and the interpretive practices through which this theorizing proceeds" (Alexander I987: 23). Finally, perhaps the most potent element of this 'encounter' is the crucial contribution of 
Alexander's creative insight, since even when he is not strictly faithful to the letter of the Durkheimian text, he has been to its spirit. It is not a question, obviously, of defending a unique or true 'spirit' of Durkheim, but rather of indicating that, through this interpretation, we can contemplate a coherent, pertinent and stimulating image of Durkheimian theory.

\section{FIRST ENCOUNTER WITH DURKHEIM: ELECTIVE AFFINITIES}

The publication of Theoretical Logic (Alexander, I982a) - the result of his doctoral thesis - marked Jeffrey Alexander's entry among the leading names of social theory, turning him into a central figure of what he himself called a "new theoretical movement" (Alexander, I987). The status of this book in the general economy of his work remains ambiguous for his readers since it already contains a kind of reckoning with his original theoretical training, strongly marked by the Marxist tradition, but still influenced by the Parsonian paradigm, and denoting an affiliation with neo-functionalism, from which he would break years later on committing to the 'cultural turn.' When asked about the meaning of these four volumes to the later development of his theory, Alexander formulated the following response:

Basically my work tries to fulfil that idea of how we understand meaning as a
dimension, and what kind of theoretical tools do we need for this. At that time
I thought that the only tools we needed was the classical tradition, plus Parsons,
that his functional approach to values was a sufficient way to talk about the
cultural dimension of meaning. The break in my work was as I came to realize
that the "values" was actually a very inadequate way. [...] Values are the way
that analysts characterize meanings, not the way actors talk about meanings
(Alexander, 20Ig: n.p.).

For this reason, scholars of Alexander's work usually recognize Theoretical Logic as the expression of a superseded project with little or no connection to the author's later theoretical developments. However, this does not apply to his analysis of Durkheim. A chronological reading of his texts reveals how the general design of his interpretative theory remains virtually intact until his most recent work. For instance, the author's chapter in The Cambridge Companion (Alexander, 2005) is just a slightly modified version of the analysis undertaken in the I980s (Alexander, I982b, I986a, I986b, I988). In subsequent texts, as we shall see, we merely find accretions and new constructions based on the argument formulated at this earlier point.

In another section of the interview, the author provides a clue to help us understand how the same author - Durkheim - was able to be maintained as a paragon of both functionalism and cultural sociology, even without the substantial alterations effected by the interpretation originally constructed by Alexander. It is a matter firstly of emphasis and secondly of a focus on change, centred more on his view of Parsonian theory and much less on Durkheim's work: 
At the time when I discovered Durkheim, I even imagined it was a new way of thinking about the author, which was in a tense relationship with Parsons's analyses of value, though I had only a very vague awareness of this when I published the book. So when I returned to Theoretical Logic, I realized that there really was a tension there concerning which my mind continued to operate at different levels. And in the following years, when I began to create a cultural sociology that conflicted with Parsons's analyses of value, I was returning to something that I had done in Theoretical Logic, but that stirred many questions in me and offered me the imaginative resources to create a different theory. (Alexander, 20I9: n.p.).

Briefly reconstructing the core of the interpretation of Durkheim developed in this seminal book, as well as in the two articles published immediately afterwards (Alexander, I982b, I986a, I986b), is thus crucial to understanding the basic structure on which other layers were gradually overlaid. In this group of texts two arguments exist, deeply interconnected, articulating the entire trajectory traced by the author. The first establishes the resolution of the antinomy between determinism and freedom as a central question of Durkheimian theory, also formulated as a tension between structure and action, or order and voluntarism (Alexander, I982b: 98-99; I986a: 9I). The second argument indicates that the resolution of this antinomy already begins to take shape in The Rules of Sociological Method (Durkheim, I895) and is consolidated with the emergence of 'religious sociology,' the first formulation of which occurs around I897 with Suicide (Durkheim, I897), reaching its peak with the publication of The Elementary Forms of the Religious Life (Durkheim, I9I2). Let us first examine, then, how these two arguments are elaborated before exploring their developments in the later phase.

The desire to reconcile objective structure with subjective freedom is not exactly new: even those authors whose work does not formulate the question in these terms would have little problem accepting this aim as a central challenge for sociology. The most intriguing aspect of Alexander's construction is the imputation to Durkheim of a supposed dispute with the Marxist paradigm, such that all the movements of the former are presented as either moving closer to or away from this tradition, the principal representative of the determinist approach - at least in the scenario depicted by the author of Theoretical Logic. Moreover, an equation is made between Marxist theory and the theories of classic economics: both represent an instrumentalist conception of human beings, implying a cosmovision that presumes action to be determined by the material structure in which it is embedded. According to Alexander, Durkheimian theory set out with the idea of breaking away from this viewpoint, but the thesis formulated in The Division of Labour in Society (Durkheim, I893) represents a detour in this movement of distancing, implying a materialist relapse in which the subject is bereft of liberty and the idea of morality depends on morphological and mechanical elements (Alexander, I982b: I07-I IO), operating as an external constraint to the subject. 
Alexander makes a Herculean effort to show how The Division of Labour in Society is proximate to the Marxist diagnosis and, above all, how Durkheim in his later texts seeks as far as possible to reject the imputations of materialism attributed to him. An impressive number of references are cited by the author to show the proximity and distance between the French sociologist and Marxism. However, this diagnosis, at least according to my analysis, remains insufficient and, I would even say, somewhat unjustified. The author successfully demonstrates how, despite the absence of solid evidence that Durkheim was familiar with Marx's texts, he undeniably had direct knowledge of some of the Marxists from his era. Nevertheless, we are not given convincing arguments concerning the importance of this alleged dispute in shaping Durkheim's thought; if not simply non-existent, it is at least marginal.

The absences are even more significant: Alexander does not mention the centrality of the debate with Kant, well-known to be a structuring dimension of Durkheim's thought (Miller, I998, I996; Hall, I987; Weiss, 2006; Jones, 200I), limiting himself to the debate with the utilitarians. Consideration of his dialogue with Kant would allow us, for example, to understand the extent to which Durkheim maintains the basic architecture of the German philosopher, while replacing the notion of transcendental reason for that of society, as well as introducing a conception of social change much closer to Hegelian philosophy. Even in relation to the general frameworks of what would eventually become the cultural sociology project, recuperating this element of Durkheimian sociology would add complexity to our understanding of the genesis, role and transformative possibilities of the symbolic elements structuring any given social context.

Another absence is the context of epistemological debate, connected to a specific conception of the objectivity of knowledge, rooted in the premises of methodological naturalism, the principle of induction and an engaged idea of science inspired by Charles Renouvier (Massella, 2006; Schmaus, 2004; Jones, I995). In sum, by emphasizing the supposed clashes and approximations with the Marxist and utilitarian tradition, Alexander's interpretation overstates its case by presenting connections whose relevance is not particularly convincing.

\section{DISCOVERING DURKHEIM'S 'FINAL PHASE': THE SYMBOLIC IS AFFECTIVE}

The structuring axis of Alexander's interpretative construction depends on his singular reading of Durkheim's first book, The Division of Labour in Society, published for the first time in I893. In Theoretical Logic, we read that in Durkheim's text, the phenomenon of the division of labour is inherently instrumental, meaning that the social order depends solely on material elements. According to the author, the change in Durkheim's view occurred a short time later with the introduction of the moral dimension into his work (Alexander, I982b: 2 I 32I5). There is thus a refusal to recognize the 1893 work as the first systematic 
essay in the field of the sociology of morality, an intention made explicit by Durkheim in the preface to the first edition of the book, a section removed from the subsequent editions for editorial reasons. In fact, at diverse moments of this work we encounter an open clash with the utilitarians, whose theories, Durkheim argued, failed precisely when it came to apprehending the moral nature of social reality.

This detail is important since it highlights the way in which Durkheim envisaged the division of labour, taken not just as a datum of morphological structure, but as itself a moral phenomenon, insofar as it engenders cooperation and social bonding, something ever present as a condition sine qua non for moral life. At a later moment in his intellectual trajectory, the author formulates more explicitly his thesis concerning the insufficiency of the division of labour for the moral maintenance of the collective life of modern societies and shifts to emphasizing the need for shared beliefs (Durkheim, 20I4), without though ever abandoning the premises set out in The Division of Labour (see Miller, I996). In reality, it is important to keep in mind that this morphological-structural dimension always remained a key element for understanding social reality, as found in the discussion later developed in Suicide or even in the introduction to the theme of collective effervescence in The Elementary Forms of Religious Life.

To comprehend the persistence of this idea it is necessary, however, to re-evaluate the meaning attributed to the idea of structure or morphology in the work of the French sociologist. Not infrequently this idea is taken in a determinist sense, as though specific arrangements in different geographic territories or variations in demographic density were facts sealing the fate of a group as a whole. Another form of understanding the question, seen from a more relational optics more in tune with the author's premises, is, I think, to take morphological structures as conditions of possibility for social interaction. This involves, therefore, constructing a sociological analysis in which the facilities and constraints to interaction between bodies and minds is taken as a relevant fact, as a premise necessary to the constitution of social bonds.

In the subsequent moments of his work we can note the introduction of new explanatory layers. It is not a question of removing the structural dimension but of the theoretical and empirical discovery of the importance - or even pre-eminence - of the symbolic dimensions, whose origin and function he seeks to investigate subsequently. In other words, Durkheim pursues an understanding of social life that consider not only the form of social relations (their frequency, approximations and distancings, pressures, etc.), but also the content of the collective representations that bind them and make them possible. It is within this broader context that we can comprehend the deepening of his studies of religion, or better, of the religious nature of collective life.

In Alexander's reading, the "transformation of association into an emotional rather than an instrumental interaction marks Durkheim's crucial break 
with his past" (Alexander, I982b: 218). Here the well-known saying "God writes straight with crooked lines" comes to mind. From the viewpoint of my argument, there exists a degree of hermeneutic fragility in the way in which Alexander reconstructs Durkheim's work, but the eventual result is both correct and innovative, allowing us to apprehend a central element overlooked by most earlier interpreters.

If I could squeeze into a few lines the treatment given to Durkheim in Theoretical Logic, I would characterize it as a creative and schematic re-reading structured around two fundamental theses: firstly, the existence of a movement of approximation and distancing in relation to a structuralist and materialist conception of social life that implied similarity with Marx's thought; and secondly the 'discovery' of the importance of the symbolic dimension, based on the ideas of emotion and the sacred. While the first of these theses is somewhat flimsy and adds little to the debate, the second is hugely innovative and contains the potential for diverse future developments, fundamental to the evolution of cultural sociology.

Before advancing to themes introduced in the subsequent works, it is worth examining a little more closely two interesting aspects of the second thesis, concerning the way in which Alexander approaches the theme of the symbolic dimension, the emotions and the sacred. Firstly, it is notable that the author perceived the importance of the theme of religion and the sacred in the general economy of Durkheim's work, but that there is practically no systematic treatment of Durkheim's most important book on the subject. The absence of The Elementary Forms of Religious Life is noteworthy, since it is merely mentioned and the analysis confined to some specific points of the book, in sharp contrast to the attention bestowed on the author's other texts. Directly associated with this too is the somewhat precarious treatment given to the theme of morality and religion, resorting, to this end, to the concept of sacred, also superficially discussed. Contrary to Alexander's (I982b: 239) assertion, the idea of the sacred is not the watershed between morality and religion - after all, morality itself is invested with a sacred element (Durkheim, I925, I992; Weiss, 2013a). This question is important since it sets limits on a series of explanatory potentials of Durkheimian theory, in particular potential advances in understanding the omnipresent nature of morality - and the sacred - in human life, including the possibility of including the moral sphere as a part of the investigations of cultural sociology.

Secondly, as the author himself has admitted, the treatment given to the role of the emotions and the symbolic dimension of life were still closely tied to a remaining influence of Parsons in his own thought. Alexander, in other words, was still looking to find an alternative way to think about the "question of order," and believed that Durkheim's work contained the elements needed to formulate a theory in which the social order is taken not as an external and oppressive structure but is constructed intersubjectively by subjects through cognitive and emotive processes also internal to them and subsequent- 
ly crystallized in institutions (Alexander, I982b: 219). Here this exposition of the emotional bases of association (Alexander, I982b: 244) is still part of his project of constructing a multidimensional theory of order and social action (Alexander, I982b: 292), but becomes increasingly central to the later construction of his truly innovative theory, developed from the cultural turn onwards, when the pre-eminence of the logos gives way to mythos.

In the two articles published some years later (Alexander, I986a, I986b), as well as those books more directly focused on establishing the bases of cultural sociology (Alexander, I988; Alexander \& Seidman, I990; Alexander, 2003), all centred on a (re)interpretation of Durkheim, we see the persistence of the thesis of internal rupture in the author's work, but we already encounter significant advances in the formulation of the underlying principles of cultural sociology. In this new context we find the first explicit discussion of the sacred and the first indication that the emotions are conceived to be part of a theory of the symbolic (Alexander, I988: 2-3).

\section{THE INVENTION OF THE CULTURALIST LINEAGE AND ITS TOTEMIC FATHER}

Alexander's re-reading of Durkheim's work initially aimed to resolve his own existential and theoretical concerns and mark a position in the debate engaged in by his masters, Parsons in particular. This allowed him to encounter a reference point capable of distancing himself from a number of awkward premises found in the Marxist tradition to which he was linked at the beginning of his intellectual trajectory. All the signs indicate, however, that this encounter with the 'Durkheim continent' represented a significant shift in direction, resulting in the production of an entirely new theoretical perspective in sociology, echoing an idea that the author himself formulates very well in the introduction to The Cambridge Companion to Durkheim:

[...] when an author's work has staying power beyond its immediate context, this being the very quality that distinguishes a truly great contribution, something much more intriguing happens. Readings proliferate that are unintended and unpredictable, with determinations that go far beyond those that could have been consciously anticipated by the maker of the original text. Time reverses the direction of influence. New contexts of interpretation come to rewrite texts as authors and theories are re-narrated for present relevance. Next, these critical interventions are themselves reworked and rethought. Eventually a layered field of immense dialogic activity is formed as words, ideas, their underlying structures of feeling and analytic choices accumulate and attach to the classical bedrock (Alexander \& Smith, 2005: I).

The above excerpt alludes to this constant alchemy in the field of social theory, reiterating the difficulty of establishing precise boundaries between things - after all, at the level of thought, everything merges and is remade all the time. This does not preclude us, though, from the task of situating crucial movements and strategies in the mapping of such processes, and Alexander's 
work offers a privileged method of doing so, since it allows us to understand certain strategies mobilized in this process of revision, fusion, construction and reconstruction.

The re-reading of Durkheim's work via a new key afforded Alexander what I consider to be his real breakthrough: the establishment of a 'culturalist lineage,' towards which diverse authors and theoretical frameworks converge, with a substantial portion of this lineage taking Durkheim as their primordial totem (Alexander, I988: 9-I0). By setting in relief the symbolic theory present in the author's work, the conditions of possibility are posed to establish a dialogue between three supposedly divergent approaches: structuralism, the Parsonian and even Weberian theory of action, and the theory of rituals. In the process, Alexander recounts the history of sociology itself:

$[\ldots]$ there is increasing agreement today that in the later period Durkheim's sociology underwent a decisive shift. It is, of course, the recognition of the crucial distinctiveness of this later work which has allowed the Durkheimian roots of contemporary cultural studies to be traced. The chapters that follow, published here for the first time, are informed by this new reading of Durkheim's work. They make their late Durkheimian explicit, even as they draw upon the full repertoire of cultural theorizing I have described. As such, they not only contribute to reintegrating the cultural field but demonstrate the possibility of a culturalist approach within the discipline of sociology more narrowly defined. [...] Yet, while these chapters bring the late Durkheim to cultural analysis, they also bring contemporary cultural analysis to Durkheim (Alexander, I988: II).

It is through a dialogue with the French author that, in fact, Alexander underlines the distance between his reading of Durkheim and the theoretical tradition arising from the impact exerted by the author of The Structure of Social Action. In his reading, Parsons's central problem related to changes that increasingly emphasized the structuralist elements of Durkheim, shifting the focus away from the more culturalist and potentially revolutionary elements of this author, particularly evident in The Elementary Forms of Religious Life. This shift in Parsons's work occurred in the I950s and I960s when his discourse on modernity as a sphere of structural differentiations became consolidated. Parsons's legacy for cultural sociology, however, did not flounder there, having been continued by three more or less direct heirs, Edward Shils and Robert Bellah, Clifford Geertz (Alexander, I988: 8-I I).

Without doubt, these two authors represent the main heirs to Parsons on American soil, in particular due to the developments in the sociology of religion, conferring special attention to the concept of the sacred. Not by chance they are presented as part of this great lineage of cultural sociology, with clear impacts of the work of these authors on his own theory since, compared with Parsons, they offer a more sophisticated development of the later phase of Durkheim's work, precisely the most influential on Alexander's own intellectual program. However, they are merely pillars in the process of constructing 
the "strong program in cultural sociology," not to be confused with this approach properly speaking - inaugurated by Alexander - precisely due to his difficulty in disentangling Durkheim from his conservative and structuralist avatars.

The French school that constitutes the base of cultural sociology represents another type of structuralism, whether in its anthropological, linguistic, semiotic or post-structuralist versions, bearing no similarity to Parsonian structural functionalism. The main figures of this part of the historical account are Ferdinand Saussure, Michel Foucault, Roland Barthes and Claude Lévi-Strauss, the latter the only one to openly admit the presence of Durkheim's influence on his work, albeit in critical form, much more closely linked to the figure of Marcel Mauss. Despite the significant differences between these authors, Alexander skilfully demonstrates a strong presence of Durkheim's late work in all these authors, even when the authors themselves make no explicit allusion. This movement is essential to Alexander's project since it allows him to draw from sources with the potential to add considerable density to his project, in cluding the assimilation of theoretical and empirical developments from other areas, central to the evolution of his own analyses concerning the social reality taken in their symbolic and performative dimension.

The same applies to the last version of this tradition, anthropological in kind, the principal representative of which is Victor Turner, considered the author to have most fully developed the theory of rituals formulated in seminal fashion by Durkheim. The originality of Alexander's reading of the theory of rituals resides in the aspects he chooses to emphasize: put otherwise, he highlights rituals not so much as meaning-creating processes and repositories of social order, but focuses attention on the idea of liminality, pointing out that "since this condition of liminal solidarity constitutes a deviant status, it often provides an opening for social change" (Alexander, I988: 9).

In fact, in this brief review we come face-to-face with one of the most interesting aspects of the tradition constructed by Alexander: his cultural sociology aims to be radical and critical. It comprises, therefore, an ambitious project based on I) the reinterpretation of classical sociology, in particular Durkheim's work, but also of Weber's interpretative sociology, which 2) enables the construction of a coherent tradition providing concepts and arguments for cultural sociology, understood 3) from a critical and revolutionary perspective - no longer in the Marxist sense, but as the potential for transformation at the level of action mediated by symbolic elements, understood in their cognitive, affective, ritual and linguistic dimension.

\section{THE 'STRONG PROGRAM': CULTURE AS TEXT AND THE CYBERNETICS OF THE SACRED}

This army of precursors rallied around the same ancestor is fully deployed by Alexander in his definition of what he calls a strong program of cultural sociol- 
ogy. In his view, other authors had constructed culturalist approximations in the context of sociology, setting out from re-readings of works by Durkheim, including the likes of Erving Goffmann and Randall Collins, but they had produced a weak version of this program by insisting on a "mechanistic and often cynical model of human interaction and emotion" (Alexander \& Smith, 2005: 8), devoid of any critical and transformative potential.

In the version narrated by the author himself (Alexander, 2003: ix-x), the initial impulse in the trajectory that led him to conceive the strong program in cultural sociology dates back to the I97os and the idea of 'symbolic realism' formulated by his then professor, Robert Bellah. However, the maturation process took almost three decades with the reinterpretation of Durkheimian sociology occupying a central place. Without any intention of identify all the premises and lineages involved in the construction of this program, my aim here is to engage in something like a 'strong Durkheimian interpretation,' so as to scrutinize the explicit and implicit concepts of Durkheim's theory that lend support to Alexander's program.

In The Meanings of Social Life (2003) the author presents the most complete and systematic version of this program, uniting texts published at the end of the I99os, heavily reworked and interconnected so as to provide solidity and coherence to his model of cultural sociology, the backdrop to all its subsequent developments.

The major point to be resolved by Alexander's cultural sociology presumes that culture is no longer understood as a narrowly cognitive dimension, but mythological, which also implies an affective dimension. Culture thus becomes understood as a text independent of its author - independent of a consciousness - which presumes another form of analysis, both structural, focused on unconscious structures, and hermeneutic, turned towards the interpretation of the meanings shared by human beings belonging to a specific collectivity (cf. Vandenberghe, 2008).

Although this conception is no novelty in the field of the human sciences, Alexander confers special attention to unconscious social processes, and emphasizes the importance of sociology in revealing them:

[...] what fascinates and frightens me are those collective forces that are not compulsory, the social forces to which we enthusiastically and voluntarily respond. If we give our assent to these, without knowing why, it is because of meaning. [...] The secret to the compulsive power of social structures is that they have an inside. They are not only external to actors but internal to them. They are meaningful. These meanings are structured and socially produced, even if they are invisible (Alexander, 2003: 4).

Consequently, the role of cultural sociology is to reveal these myths internalized by men and women in order to enable the creation of new myths in a more autonomous form. For this reason, Alexander conceives his sociol- 
ogy to be a form of social psychoanalysis. On this point, I see the proposal made by cultural sociology as offering a contemporary and in principle much more plausible elaboration - almost aporetic - of Durkheim concerning the spirit of autonomy as a third element of morality, constitutive of modern societies (Durkheim, 2008: Chapters 7-8). This aspect presumes the possibility of constituting a type of morality invested with rationality, understood as an idea of transparency and reflexivity, but never fully articulated with his understanding of morality as a phenomenon imbued with a sacred dimension. In other words, the question never resolved by Durkheim relates to the possibility of sustaining the imperative and sacred dimension of a determined moral principle even after the disclosure of its social basis.

Alexander radicalizes Durkheim's position by showing how the potential for 'consciousness' only amplifies the margin for action, without implying the elimination of the social forces that act on subjects. Here we can see the extent to which Alexander is also informed by psychoanalysis, appropriating its understanding of how the unconscious operates. Revealing its logic, its language, does not imply removing its power, only creating the possibility of introducing displacements and creating new meanings. This is an important contribution of the cultural turn in sociology, deepening Durkheim's original intuitions by stripping them of the scientificist and rationalist elements. As I indicated at the outset of this text, this is a procedure similar to Lacan's vis-à-vis Freudian theory, since conceiving social structure as a symbolic dimension is equivalent to show that the unconscious operates in the life of the subject as a language.

In the context of the strong program, Durkheimian theory is mobilized to show that culture is not just any text, but a text punctuated by correlated signs and symbols, primordially structured as 'binary oppositions.' In schematic terms, we can highlight three elements taken from Durkheimian sociology that are central to the invention of cultural sociology. These are: collective representations, which found the very idea of the symbolic that enables the emphasis on meaning; the duality between the sacred and profane, which sediments the notion of a binary structure; and, finally, the notion of creative practice attributed to rituals, which permits Alexander to introduce a dynamic dimension, implying that culture is not just autonomous but also creative.

Closing ranks with Saussure and Levi-Strauss, Alexander comes to formulate an idea of culture as a sphere autonomous from other dimensions of social life, with somewhat arbitrary meanings, generated through the system of signs itself, articulated as a web in which the actions of subjects unfold. This web of meanings acquires the status of an objective structure, subjectivized through its internalization by subjects, thereby turning into internal reference points for action. To understand the singularity of this approach, we need to take a step back, recuperating the Durkheimian concept of collective representation (Durkheim, I895, I9I2). The status of this concept is widely debated in the 
field of Durkheimian studies, with diverse interpretative implications (cf. Oliveira, 20I2). But in the context that interests us here, collective representation is taken as symbolic representation.

Alexander mobilizes this category as a form of thinking about the existence of an element that enables the mediation between the social and the subjective, whose nature is not material but ideal. Of course, the notion of representation itself contains a mental connotation, but the main contribution of Durkheimian sociology is to show that beyond individual representations, which depend exclusively on the mental life of singular subjects, an entire set of representations exist that are collectively produced. These are the expression of life in common and, although elaborated in a specific context, marked by particular power relations, by a material structure and so on, they enjoy relative autonomy from the latter. In other words, they are not superstructural epiphenomena. However, they are also not the creations of singular subjects, meaning that they follow their own logic, related to the structure of the cultural sphere itself, and they express elements of reality in symbolic - that is, mediated and transfigured - form.

Collective representations are and are not created by subjects; they are and are not internalized by them. Every representation is a human creation and thus presumes the involvement of concrete subjects. However, they are never the creation of a singular subject, but the result of an interaction that, in itself, involves elements that are not only cognitive but also emotive. After all, one of the basic premises of Durkheimian sociology is that every association produces a particular type of emotion, such that collectively constructed representations also partake of this characteristic and, precisely for this reason, acquire a status that is more mythological than logical. Finally, they are internalized by subjects, but not in conscious form, and never completely. For this reason no individual possesses in full the set of representations that circulate in any given social context.

The very process of internalization is already a 'version,' which is why the hermeneutic project at the base of Alexander's cultural sociology is not centred on individual representations, much less on conscious representations for action. It comprises a hermeneutics focused on the apprehension and interpretation of the symbolic representations that circulate in a determined context and that themselves constitute the web of shared meanings that allow communication between subjects, even when the latter are unaware of the fact. To this end, Alexander formulates a new version of interpretative sociology in terms set down by Weber, but also incorporating the idea of thick description, in a sense that recuperates and updates Geertz, making it possible to access multiple signs and their articulations, constitutive of culture.

However, this properly hermeneutic dimension is complemented by a structural analysis with the purpose of identifying what is invisible to the eyes - 
in other words, what operates as an unconscious structure. In other words, while culture produces its symbols and discourses autonomously, this does not occur in random fashion. Rather, it obeys schemas that are constitutive of it. Here again Alexander's proposal focuses on Durkheimian theory, taking as a guideline Durkheim's conception of the duality between the sacred and the profane, as formulated in The Elementary Forms of Religious Life (Alexander, 2003: 24).

This conceptual pair is initially presented by Durkheim as a form of circumscribing the religious domain from other spheres of social life. However, as his text unfolds, they come to operate as omnipresent markers that establish the difference between the everyday and ordinary - what in Weber's sociology is encompassed by the notion of routine - and what is exceptional and imbued with respect, as though cloaked in an aura.

The essential feature of the sacred is to be placed 'apart' and protected by an interdiction. Both good and evil share this aspect, characterizing what the author calls the "ambiguity of the sacred" (Pickering, I984; Weiss, 2013a, $2013 b)$. Both are extraordinary in kind, protected by sanctions and rituals that keep them separate, avoiding contaminations. On the other hand, rituals also exist whose role is to establish a demarcation line vis-à-vis the profane universe, defining ordinary, everyday things as a separate domain. Profane includes everything that is not sacred, not invested with exceptionality. Consequently, the sacred is what really needs to be explained.

In Durkheimian theory, the sacred is not a substance, nor an inherent characteristic, but a quality attributed to things, ideas and persons. It is a marker that delimits what was invested with a high level of emotion due to having been produced in moments of particular emotional intensity, characterized as instances of collective effervescence. In Alexander's theory, this duality performs the role of a structural marker capable of conferring a logic to the symbolic web, invisible to the subjects who move within it, but apprehensible by the social analyst, so long as he or she is capable of understanding the subjacent codes.

This, in turn, is a malleable structure, one that acquires specific formats in specific social contexts, always open to mutation but invariably present. To complete this picture of an invisible but perceptible world, structured but malleable, we can turn to a final concept extracted from this Durkheimian matrix, the concept of ritual, reworked in different directions by two of his supposed heirs, also mobilized by Alexander - namely, Victor Turner and Erving Goffmann. In the theory formulated by Durkheim, ritual is a privileged form of practice whose prerogative is to organize experience, create the feeling of transcendence, and enable significant changes.

Both collective representations and the duality between the sacred and the profane possess the force of transcendental categories, exerting a privileged influence on the thought and action of subjects, only insofar as their produc- 
tion is linked to ritual contexts that generate collective effervescence. Not every situation of effervescence is encapsulated in the form of a properly ritual action, but ritual is a moment of exceptional relevance in symbolic production since it comprises a shared practice based on some degree of intentionality, but a practice that ends up creating new symbolic elements that, not infrequently, pass unnoticed by the actors immersed in this process.

A deeper understanding of the potential of this concept was central to introducing a more dynamic and creative dimension to Alexander's theoretical schema, enabling the opening of a new path within the project of cultural sociology, encapsulated in the idea of a 'performative turn' (Alexander, Giesen \& Mast, 2006). Even though reworked via many other interpretations, the concept of ritual provides the main clues to comprehending the potential mediation between the worlds of meaning and action. As the authors state in the introduction to the book Social Performance: Symbolic Action, Cultural Pragmatics and Ritual, "it is only through the actions of concrete social actors that meaning's influence is realized" (Alexander \& Mast, 2006: I6).

In his understanding of the meaning and role of rituals, Alexander echoes the significance attributed by Durkheim to this phenomenon, taking it as the fundamental process in the production of effervescence, the basic condition for structuring the beliefs and values of the social world (Weiss, 2012). In so doing, the author succeeds in highlighting a nuance seldom perceived in Durkheim's work: the thesis of common action as a creator of shared meanings or, further still, of the interaction between subjects as a fulcrum productive of the social world:

Rituals are episodes of repeated and simplified cultural communication in which the direct partners to a social interaction, and those observing it, share a mutual belief in the descriptive and prescriptive validity of the communication's symbolic contents and accept the authenticity of one another's intentions. It is because of this shared understanding of intention and content, and in the intrinsic validity of the interaction, that rituals have their effect and affect (Alexander, 2006a: 29).

Here Alexander aims to establish a theory of cultural pragmatics capable of transcending the classic division in studies of culture, polarized between "structuralist theories that treat meaning as a text and investigate the patterning that provides relative autonomy" and "pragmatic theories that treat meaning as emerging from the contingencies of individual and collective action - socalled practices - and that analyze cultural patterns as reflections of power and material interest" (Alexander, 2006a: 29). As well as the dimension of autonomy, the author also adds the requirement of sincerity, without which contemporary performance lacks validity, even though such sincerity need not require real authenticity but can be feigned (cf. Vandenberghe, 2008). To a certain extent, the author seems to carry forward the research program essayed by Durkheim, 
setting out from the idea of a religious sociology, to build bridges between 'traditional' and 'modern' societies, pointing to the different forms through which the same dynamic is reproduced and/or updated.

\section{FINAL CONSIDERATIONS}

Since the I980s, Jeffrey Alexander's path has intersected with Émile Durkheim's work, immediately transformed into a structuring element of his thought. Revisited numerous times, Durkheim's theory remained a constant reference, even when covered by new layers, more directly related to Alexander's most recent concerns, such as the theorization of contemporary political-cultural space as a civil sphere (Alexander, 2006b), or in his discussions of collective trauma (Alexander, 2013b; Eyerman, Alexander \& Breese, 20I5; Alexander et al., 2004) or on the perverse consequences of modern logic (Alexander, 2013a).

As we have seen, this encounter was accompanied by creative reinterpretations, sometimes more, sometimes less rooted in literal references to Durkheim's texts, but always fostering the emergence of a creative and relevant potency in the author's work, frequently buried by the sociological tradition. This inventive and innovative reading remained somewhat controversial in the context of Durkheimian debates, however, both because of the challenge to orthodoxy posed by its construction of a 'culturalist' image of Durkheim, and because of its singular conception of the role of the classics in sociology and the ways to approach them.

His closer relationship with the work of the French sociologist began in the I980s at an event in Germany held to discuss Durkheim's sociology of religion, which generated an important dialogue around the idea of symbolic classification, paving the way for the encounter with other authors linked to this tradition who would later prove central to the construction of his strong program in cultural sociology (cf. Mast, 20I5). Gradually this re-reading of Durkheim's work rooted in his own intellectual concerns acquired the status of a new interpretative current that, paradoxically, and perhaps despite his own intentions, ended up occupying the position of a narrative contested with others.

This aspect was further accentuated with the publication of a collection entirely dedicated to Durkheim, The Cambridge Companion for Durkheimian Studies. At the time of publication, this compendium provoked diverse reactions, both in the form of reviews and in more informal exchanges within the network of Durkheimian scholars, split between measured praise (Rosati, 2007) and sharp critique (Boudon, 2006: I47). In the understanding of part of this academic community, a Companion should seek to offer a sufficiently exhaustive survey of the theme in question, and this was the quality questioned by researchers who claimed that the version of Durkheim presented in the book evinced a heavily culturalist bias (Pearce, 2006: I57), even though its editors had reaffirmed their intention to include the leading contemporary researchers on Durkheim's work (Smith \& Alexander, 2007: I26). 
Without wishing to engage in this dispute, perhaps the most important aspect to emphasize is that the decisive element in the noise generated by this critical reception is, in effect, the different forms of envisaging the classic tradition. Ultimately, the question still remains: what use are the classics? If we agree with Alexander that they are necessary both as a mythological reference point to ensure a space of communication between members of the sociological community and because of the exceptional nature of the narratives that they themselves constructed, perhaps we can regard "Alexander's Durkheim" as yet another version of the myth.

Bringing this debate to Brazil, I suggest that appropriating Alexander's interpretation of Durkheim's work is fundamental to interrogating the way in which Durkheim has repeatedly been presented in the country, still heavily linked to a particular interpretative legacy canonized by Parsons, in the context of which Durkheim's theory seems confined to the pigeonhole of functionalism with all the limitations this implies. In abandoning neo-functionalism and moving towards a cultural sociology, Alexander adds to new meaning to Durkheim's work through a hermeneutic endeavour that results in the construction of an alternative image.

Reconstructing the general architecture of cultural sociology, profoundly imbricated with this reinterpretation of Durkheim, opens up innumerable possibilities for narrating another version of the classics of sociology, leading to the construction of new narratives capable of transforming our potential relationship with the history, past and future, of sociology itself. It is not just a question of once again adopting ipsis literis foreign constructions of our 'origin myth' (Connell, 2012), but of amplifying the number of interlocutors invited to the debate. In this way, we can remain more faithful to our anthropophagic vocation, constructing our own versions of the myth, rooted in a symbolic universe originating from our own actions and concerns.

Received on I/IO/20I8 | Revised on 30/I2/2018 | Approved on 5/I/20I9

Raquel Weiss has a Master's degree in Sociology and a PhD in Philosophy from Universidade de São Paulo (USP). She is a professor in the Department of Sociology at Universidade Federal do Rio Grande do Sul (UFRGS) and the director of the Brazilian Centre of Durkheimian Studies. 


\section{NOTES}

I My thanks to Frédéric Vandenberghe for his critical and attentive reading of the manuscript and for his valuable suggestions. I also thank the anonymous reviewers whose comments where decisive in shaping the final form of this article.

2 The interview was conducted as part of the 'Sociological Theory in Contemporary Sociology' project with the support of CNPq, and it is fully published in portughese at <https://blogdosociofilo.com/2019/02/18/o-papel-da-teoria-sociologica-na-sociologia-contemporanea-entrevista-com-jeffreyalexander/>. An edited version of the interview is available at <https://youtu.be/AyhUV4kLdXw>.

3 The field of Durkheimian studies is not precisely delimited. There is no canonical reference point establishing critetia of belonging, nor any clear institutional or disciplinary boundaries. Broadly speaking, I refer to the group of researchers more or less linked to the group that formed around Philipe Besnard, in Paris, back in the I970s, and later around the British Center for Durkheimian Studies in Oxford and the journal Durkheimian Studies/Études Durkheimiennes (see Weiss \& Benthien, 2017).

\section{BIBLIOGRAPHY}

Alexander, Jeffrey C. (20I9). O papel da teoria sociológica na sociologia contemporânea - entrevista a Raquel Weiss. Blog do Sociofilo. Available at <https://blogdosociofilo. com/2019/02/I8/o-papel-da-teoria-sociologica-na-sociologia-contemporanea-entrevista-com-jeffrey-alexander/>. Accessed I8/2/20I9.

Alexander, Jeffrey C. (2013a). The dark side of modernity. Cambridge: Polity.

Alexander, Jeffrey C. (2013b). Trauma: A social theory. Cambridge: Polity.

Alexander, Jeffrey C. (2006a). Cultural pragmatics: social performance between ritual and strategy. In: Alexander, Jeffrey; Giesen, Bernhard \& Mast, Jason (eds.). Social performance: symbolic action, cultural pragmatics and ritual. Cambridge/New York: Cambridge University Press, p. 29-89. 
Alexander, Jeffrey C. (2006b). The civil sphere. Oxford: Oxford University Press.

Alexander, Jeffrey C. (2005). The inner development of Durkheim's sociological theory: from early writings to maturity. In: Alexander, Jeffrey C. \& Smith, Philip. (eds.). The Cambridge companion to Durkheim, p. I36-I59. Available at <https://www.cambridge.org/core/books/cambridgecompanion-to-durkheim/inner-development-of-durkheims-sociological-theory-from-early-writings-to-maturity/C3EC993AFB6CF27564FB4DB6B8C39267>. Cambridge: Cambridge University Press.

Alexander, Jeffrey C. (2003). The meanings of social life: a cultural sociology. Oxford: Oxford University Press.

Alexander, Jeffrey C. (1988). Durkheimian sociology : cultural studies. Cambridge: Cambridge University Press.

Alexander, Jeffrey. (I987). O novo movimento teórico. Revista Brasileira de Ciências Sociais, 2.

Alexander, Jeffrey C. (I986a). Rethinking Durkheim's intellectual development I: on "Marxism" and the Anxiety of Being Misunderstood. International Sociology, I/I, p. 9II07.

Alexander, Jeffrey C. (I986b). Rethinking Durkheim's intellectual development II: working out a religious sociology. International Sociology, I/2, p. I89-20I.

Alexander, Jeffrey C. (I982a). Theoretical logic in sociology. London: Routledge \& Kegan Paul (4 vols.).

Alexander, Jeffrey C. (1982b). Theoretical logic in sociology. Vol. 2: The antinomies of classical thought: Marx and Durkheim. London: Routledge \& Kegan Paul.

Alexander, Jeffrey C. \& Mast, Jason. (2006). Introduction: Symbolic action in theory and practice: the cultural pragmatics of symbolic action. In: Alexander, Jeffrey; Mast, Jason \& Giesen, Bernhard (eds.). Social performance: symbolic action, cultural pragmatics and ritual. Cambridge/New York: Cambridge University Press, p. I-27.

Alexander, Jeffrey C. \& Seidman, Steven. (I990). Culture and society: contemporary debates. Cambridge: Cambridge University Press.

Alexander, Jeffrey C. \& Smith, Philip. (2005). Introduction: The new Durkheim. In: The Cambridge companion to Dur- 
kheim. Cambridge/New York: Cambridge University Press, p. I-30.

Alexander, Jeffrey C.; Giesen, Bernhard \& Mast, Jason L. (2006). Social performance: symbolic action, cultural pragmatics, and ritual. Cambridge: Cambridge University Press.

Alexander, Jeffrey C. et al. (2004). Cultural trauma and collective identity. Berkeley: University of California Press.

Boudon, Raymond. (2006). Nouveau Durkheim? Vrai Durkheim? In: Alexander, Jeffrey C. \& Smith, Philip (eds.). Durkheimian Studies/Études Durkheimiennes, I2, p. I37-I48.

Connell, Raewyn. (2012). A iminente revolução na teoria social. Revista Brasileira de Ciências Sociais, 27/80, p. 9-20.

Durkheim, Émile. (2014). O individualismo e os intelectuais. São Paulo: Edusp. (Biblioteca Durkheimiana, primeiro volume).

Durkheim, Émile. (2008). A educação moral. Petrópolis: Vozes.

Durkheim, Émile. (1992). L'enseignement de la morale à l'école primaire. Reuue Française de Sociologie, 33, p. 609-623. Durkheim, Émile. (I925). L'éducation morale. Paris: F. Alcan. Durkheim, Émile. (I9I2). Les formes élémentaires de la vie religieuse: le système totémique en Australie. Paris: F. Alcan. Durkheim, Émile. (I897). Le suicide, étude de sociologie. Paris: F. Alcan.

Durkheim, Émile. (I895). Les règles de la méthode sociologique. Paris: F. Alcan.

Durkheim, Émile. (1893). De la division du travail social. Paris: Alcan.

Eyerman, Ronald; Alexander, Jeffrey C. \& Breese, Elizabeth Butler. (20I5). Narrating trauma: on the impact of collective suffering. London: Routledge.

Hall, Robert T. (1987). Émile Durkheim : ethics and the sociology of morals. New York/London: Greenwood.

Jones, S. G. Stedman. (I995). Charles Renouvier and Émile Durkheim: "Les règles de la méthode sociologique". Sociological Perspectives, 38/I, p. 27-40.

Jones, Susan Stedman. (200I). Durkheim reconsidered. Cambridge: Polity. 
Massella, Alexandre Braga. (2006). O naturalismo metodológico de Émile Durkheim. São Paulo/Goiânia: Humanas/ Editora UFG.

Mast, Jason L. (2015). Alexander, Jeffrey C. (I947-). In: Wright, J.D. (ed.). International Encyclopedia of the Social \& Behavioral Sciences (Second Edition). Oxford: Elsevier, p. 523528. Available at <http://www.sciencedirect.com/science/ article/pii/B97800809708686II43I >. Accessed 30/I2/20I8. Miller, William Watts. (I998). Durkheim, Kant, the immortal soul and God. In: Allen, N.J.; Pickering, W.S.F. \& Miller, W.W. (eds.). On Durkheim's Elementary Forms of Religious Life. London/New York: Routledge.

Miller, William Watts. (I996). Durkheim, morals and modernity. London/Montreal: UCL Press/McGill-Queen's University Press.

Nisbet, Robert A. (1952). Conservatism and sociology. The American Journal of Sociology, 58/2, p. I67-I75.

Oliveira, Márcio de. (20I2). O conceito de representações coletivas: uma trajetória da Divisão do Trabalho às Formas Elementares. Debates do NER, I/22, p. 67-94.

Pearce, Frank. (2006). A modest companion to Durkheim. In: Alexander, Jeffrey C. \& Smith, Philip (eds.). Durkheimian Studies/Études Durkheimiennes, I2, p. I49-I60.

Pickering, W. S. F. (I984). Durkheim's sociology of religion : themes and theories. London: Routledge \& Kegan Paul.

Rosati, Massimo. (2007). Recovering Durkheim's "Second Program of Research": Roy Rappaport and Jeffrey C. Alexander. Durkheimian Studies/Études Durkheimiennes, I3, p. I05-I2I.

Schmaus, Warren. (2004). Rethinking Durkheim and his tradition. Cambridge: Cambridge University Press.

Smith, Philip \& Alexander, Jeffrey C. (2007). Imagining Durkheim: the Cambridge companion and two recent review essays. Durkheimian Studies/Études Durkheimiennes, I3, p. I25-I29.

Vandenberghe, Frédéric. (2008). The cultural transformation of the public sphere: sociological inquiry into a category of American society. Constellations, I5/3, p. 422-434. 
Weiss, Raquel. (2013a). Do mundano ao sagrado: o papel da efervescência na teoria moral durkheimiana, Horizontes Antropológicos, I9/40, p. 395-42I.

Weiss, Raquel. (2013b). Efervescência, dinamogenia e a ontogênese social do sagrado. Mana, I9/I, p. I57-I79.

Weiss, Raquel. (2012). From ideas to ideals: effervescence as the key to understanding morality. Durkheim Studies, I8, p. 8I-97.

Weiss, Raquel. (2006). Émile Durkheim e a ciência da moral. Dissertação de Mestrado. PPGS/Universidade de São Paulo. Weiss, Raquel \& Benthien, Rafael Faraco. (2017). Ioo anos sem Durkheim. Ioo anos com Durkheim. Sociologias, I9/44, p. 16-36. 


\section{ENTRE O ESPÍRITO E A LETRA: A TEORIA DURKHEIMIANA NA SOCIOLOGIA CULTURAL DE JEFFREY ALEXANDER \\ Resumo}

A obra de Émile Durkheim é a pedra angular na arquitetônica da sociologia cultural de Jeffrey Alexander, a ponto de ser virtualmente impossível discernir com precisão em qual ponto termina o movimento de interpretação e começa a construção de uma nova teoria. Neste artigo, mostro os pontos nodais da leitura de Alexander da obra de Durkheim, discutindo como determinados conceitos e argumentos foram cuidadosamente pinçados para estabelecer as bases do programa forte em sociologia cultural, inclusive da "virada performativa". Ao fazê-lo, saliento virtudes e fragilidades dessa leitura, mostrando existir uma importante expressão de seu "espírito", mesmo quando não há fidelidade à "letra". Em suma, Alexander opera, em relação a Durkheim, uma tradução capaz de atualizar suas potencialidades, purgando-o de suas premissas positivistas e tornando-o mais apto à compreensão do mundo social entendido enquanto teia de significados socialmente criados e partilhados.

\section{BETWEEN THE SPIRIT AND THE LETTER: DURKHEIMIAN THEORY IN THE CULTURAL SOCIOLOGY OF JEFFREY ALEXANDER}

Émile Durkheim 's work forms the cornerstone of Alexander's cultural sociology, to the point where it becomes virtually impossible to discern precisely where the process of reinterpretation stops and the construction of a new theory begins. In this article I aim to show the cardinal points of Alexander's reading of Durkheim's work, discussing how certain concepts and arguments are carefully selected in order to establish the bases of the strong program in cultural sociology, including in its 'performative turn.' In so doing, I highlight both strong and weak points in his reading of Durkheim's texts, showing that there is an important expression of its 'spirit' even when he is not faithful to its 'letter.' In short, Alexander's approach to Durkheim, a translation capable of actualizing its potentialities, purges his work of positivistic premises and adapts his theory to a comprehension of the social world, understood as a mesh of socially created and shared meanings.
Palavras-chave

Émile Durkheim; Jeffrey Alexander; sociologia cultural; virada performativa; sociologia clássica.

Keywords

Émile Durkheim; Jeffrey Alexander; cultural sociology; performative turn; classical sociology. 